\title{
Cutting-edge genetics in obsessive-compulsive disorder
}

\author{
Leonardo Cardoso Saraiva ${ }^{1}$ Carolina Cappi ${ }^{1}$ Helen Blair Simpson ${ }^{2,3 \mathrm{X}}$ Dan J. Stein ${ }^{4 \mathrm{x}} \quad$ Biju Viswanath ${ }^{5}$ \\ Odile A. van den Heuvel ${ }^{6}$ Y.C. Janardhan Reddy ${ }^{7}$ Euripedes C. Miguel ${ }^{1} \quad$ Roseli G. Shavitt ${ }^{1 *}$ \\ ${ }^{1}$ Department \& Institute of Psychiatry, Hospital das Clinicas HCFMUSP, Faculdade de Medicina, Universidade de Sao Paulo, Sao Paulo, SP, Brazil \\ ${ }^{2}$ Columbia University Irving Medical Center, Columbia University, New York, NY, 10032, USA \\ ${ }^{3}$ The New York State Psychiatric Institute, New York, NY, 10032, USA \\ ${ }^{4}$ SA MRC Unit on Risk \& Resilience in Mental Disorders, Department of Psychiatry \& Neuroscience Institute, University of Cape Town, Cape Town, South Africa \\ ${ }^{5}$ Molecular Genetics Laboratory, National Institute of Mental Health \& Neurosciences (NIMHANS); Accelerator Program for Discovery in Brain disorders using \\ Stem cells (ADBS) Laboratory, NIMHANS, Bangalore, India \\ ${ }^{6}$ Amsterdam University Medical Centers, Vrije Universiteit Amsterdam, Department of Psychiatry, Department of Anatomy \& Neuroscience, Amsterdam \\ Neuroscience, Amsterdam, Netherlands \\ ${ }^{7}$ Obsessive-Compulsive Disorder (OCD) Clinic, Department of Psychiatry, NIMHANS, Bangalore, India
}

${ }^{\mathrm{x}}$ Equal contributors

\begin{abstract}
This article reviews recent advances in the genetics of obsessive-compulsive disorder (OCD). We cover work on the following: genome-wide association studies, whole-exome sequencing studies, copy number variation studies, gene expression, polygenic risk scores, gene-environment interaction, experimental animal systems, human cell models, imaging genetics, pharmacogenetics, and studies of endophenotypes. Findings from this work underscore the notion that the genetic architecture of OCD is highly complex and shared with other neuropsychiatric disorders. Also, the latest evidence points to the participation of gene networks involved in synaptic transmission, neurodevelopment, and the immune and inflammatory systems in this disorder. We conclude by highlighting that further study of the genetic architecture of OCD, a great part of which remains to be elucidated, could benefit the development of diagnostic and therapeutic approaches based on the biological basis of the disorder. Studies to date revealed that OCD is not a simple homogeneous entity, but rather that the underlying biological pathways are variable and heterogenous. We can expect that translation from bench to bedside, through continuous effort and collaborative work, will ultimately transform our understanding of what causes OCD and thus how best to treat it.
\end{abstract}

\section{Keywords}

obsessive-compulsive disorder, genetics, genomics

\section{Peer Review}

The peer reviewers who approve this article are:

1. Adriana Sampaio, Psychological Neuroscience Lab, CIPsi, School of Psychology, University of Minho, Braga, Portugal Competing interests: No competing interests were disclosed.

2. Christopher Pittenger, OCD Research Clinic, Yale University, New Haven, Connecticut Competing interests: Chris Pittenger has collaborated with Cappi C, Miguel EC, van den Heuvel OA, Simpson HB, Stein DJ, Reddy YC in the past 3 years on consortium reviews. 
*Corresponding author: Roseli G. Shavitt (roseligshavitt@gmail.com)

Competing interests: The author(s) declare that they have no competing interests.

Grant information: DJS has received research grants and/or consultancy Honoraria from Lundbeck and Sun.HBS has received research support for an industry-sponsored clinical trial from Biohaven Pharmaceuticals, royalties from UpToDate Inc., and a stipend from the American Medical Association for her role as Associate Editor of JAMA Psychiatry. RGS has received travel grants from Lundbeck and Libbs. The other authors have no funding information to declare.

The funders had no role in study design, data collection and analysis, decision to publish, or preparation of the manuscript.

Copyright: $\odot 2020$ Shavitt RG et al. This is an open access article distributed under the terms of the Creative Commons Attribution License, which permits unrestricted use, distribution, and reproduction in any medium, provided the original work is properly cited.

How to cite this article: Saraiva LC, Cappi C, Simpson HB, Stein DJ, Viswanath B, van den Heuvel OA, Reddy JYC, Miguel EC and Shavitt RG.

Cutting-edge genetics in obsessive-compulsive disorder. Faculty Reviews 2020 9:(30) https://doi.org/10.12703/r/9-30

Published: 23 Dec 2020, Faculty Reviews 9:(30) https://doi.org/10.12703/r/9-30 


\section{Introduction}

Obsessive-compulsive disorder (OCD) is a neuropsychiatric disorder characterized by intrusive thoughts (obsessions) and repetitive behaviors (compulsions) $)^{1}$. With a lifetime prevalence of $2-3 \%$ and a typically chronic course ${ }^{2}$, OCD is associated with considerable role impairment ${ }^{3}$, reduced quality of $\operatorname{life}^{4}$, and morbidity ${ }^{5}$. Moreover, individuals with OCD have an elevated mortality risk independently of the effects of comorbidities ${ }^{6}$.

First-line treatments for OCD include both pharmacological and cognitive-behavioral approaches ${ }^{7}$; alone or combined, these can help about half of patients to achieve minimal symptoms ${ }^{8}$. The development of more targeted and effective treatment interventions may benefit from further understanding of the underlying etiology of $\mathrm{OCD}$, including underlying genetic mechanisms. Here we review recent advances in OCD genetics research, including genome-wide association studies (GWAS), whole-exome sequencing (WES) studies, copy number variation (CNV) studies; gene expression, polygenic risk score (PRS), gene-environment interactions, experimental animal systems, human cell models, imaging genetics, pharmacogenetics, and studies of endophenotypes. We suggest that recent work converges in pointing out that genes involved in synaptic transmission, neurodevelopment, and the immune and inflammatory systems are involved in the pathophysiology of OCD (Figure 1). Given the genetic overlap between OCD and related disorders, further work is needed to assess the specificity of this involvement.

\section{From genetic epidemiology to genetic architecture}

Family and twin studies are useful for exploring genetic and environmental contributions to a disease. In this context, familiality refers to increased clustering of a disorder amongst families ${ }^{9}$. Consistent with multiple previous studies ${ }^{10-12}$, a recent family study in Sweden provided further evidence for the familiality of OCD, especially when associated with tics ${ }^{13}$.
Heritability can be defined as the proportion of variance in a phenotypic trait attributable to additive genetic effects (i.e. narrow-sense heritability, $h^{2}$ ) or to total genetic effects (i.e. broad-sense heritability, $\left.H^{2}\right)^{14}$. Henceforth in this article, narrow-sense heritability $\left(h^{2}\right)$ will be referred to as heritability. Past twin studies have estimated the heritability of OCD to range from 27 to $65 \%$, and a recent heritability estimate of $74 \%$ was reported for obsessive-compulsive traits in a pediatric nonclinical twin cohort $^{16}$.

The heritability of OCD encourages further work on the genetics of this disorder, with the hope that this will, in turn, contribute to the development of more precise diagnostic and therapeutic approaches ${ }^{17}$. The term "genetic architecture" refers to the overall number, effect size, population frequency, and interactions of genetic variants associated with a phenotype ${ }^{18}$. Genetic studies that contribute to elucidating genetic architecture include GWAS, WES studies, CNV studies, gene expression analysis, gene-environment interaction studies, experimental models with animal and human cells, imaging genetics studies, pharmacogenetic studies, and studies of endophenotypes. We consider each in turn, presenting a summary of all of the cited studies after the section describing an exploratory model of the genetic architecture of OCD (Table 1).

\section{Genome variants}

Early studies on the genetics of OCD focused on candidate gene association studies ${ }^{15}$. Because of their insufficient power and biased a priori hypotheses, these studies produced rather inconsistent findings and are now considered obsolete ${ }^{19}$. The development of novel methods capable of assessing the entire genome, coupled with the recruitment of larger samples, allowed the undertaking of unbiased and powerful genetic investigations ${ }^{19}$. In this regard, cumulative evidence supports the idea that both common and rare genome variants contribute to the polygenic architecture of psychiatric disorders ${ }^{20}$.

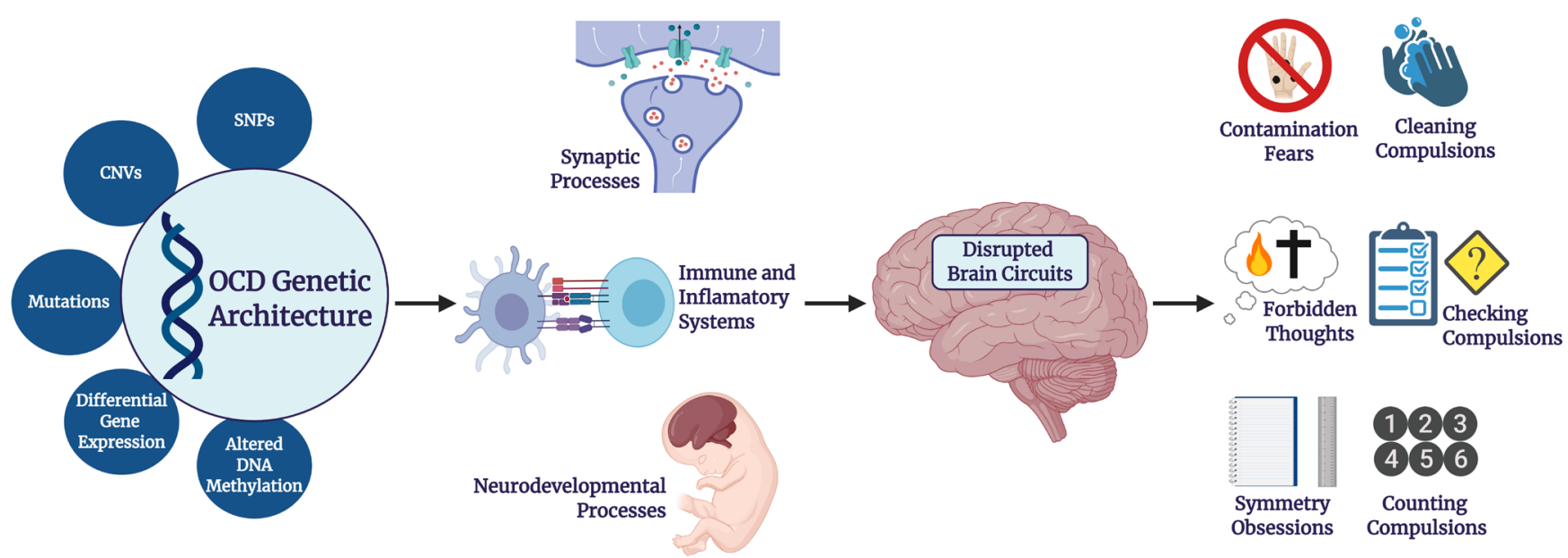

Figure 1. From genetic architecture to obsessive-compulsive disorder (OCD) symptomatology. The genetic architecture of $O C D$ presumably underlies alterations in biological pathways, which in turn lead to disrupted brain circuits and OCD symptoms. CNV, copy number variant; SNP, single nucleotide polymorphism. 


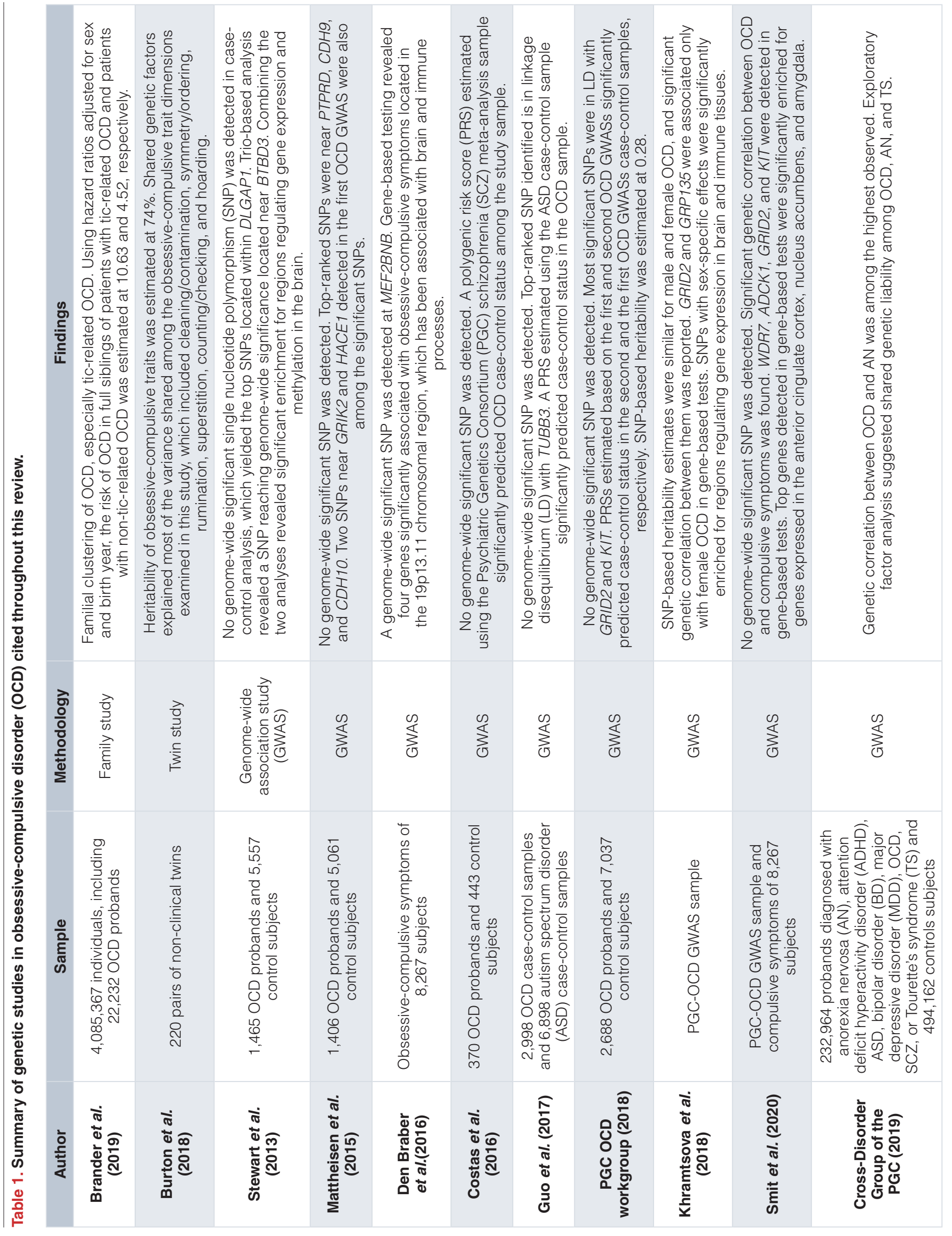




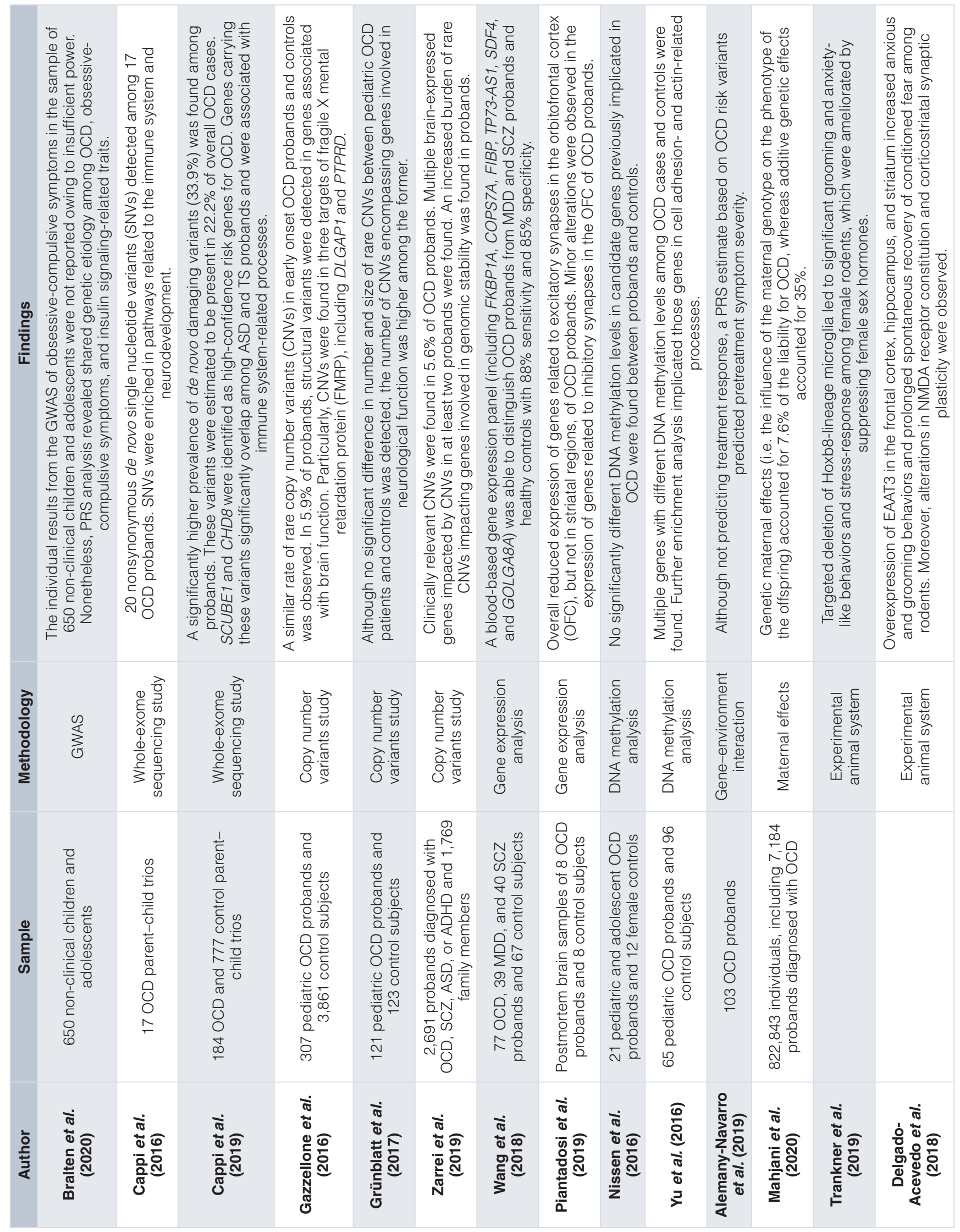




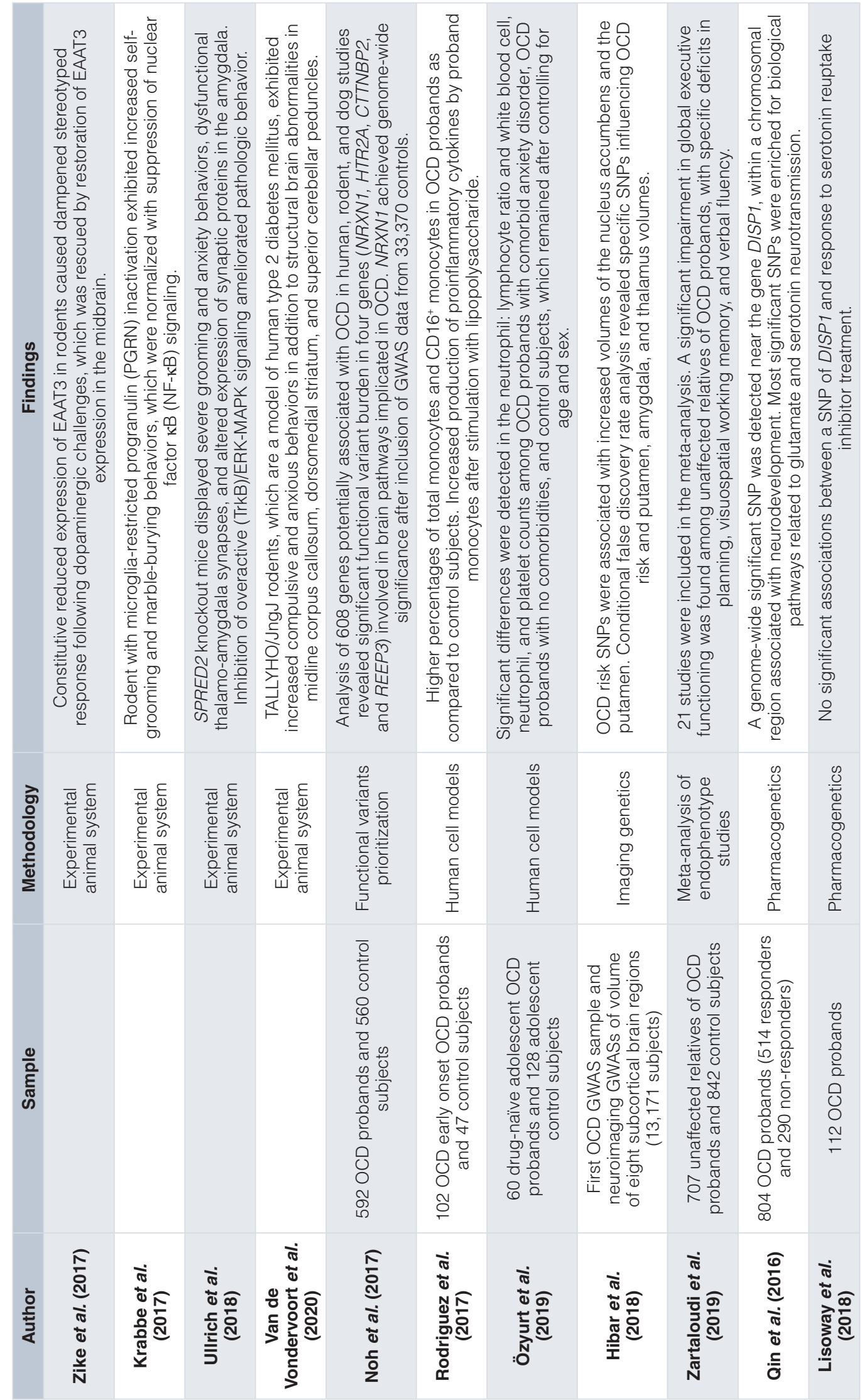


Accordingly, distinct methods have been recently used to detect genome variants associated with OCD, as described below.

\section{Common variants}

GWASs employ a case-control design to detect single nucleotide polymorphisms (SNPs) (Figure 2) associated with a disorder $^{21}$, with significance thresholds set at $P=5 \times 10^{-822}$. A range of secondary analyses of GWAS data can be conducted to further probe the relevant genetic architecture ${ }^{23}$. Such analyses include determining the portion of heritability conferred by the SNPs investigated in a GWAS, defined as SNP-based heritability $\left(h_{\mathrm{SNP}}^{2}\right)^{24}$, estimating the degree of shared genetic architecture between disorders by determining their genetic correlation $^{25,26}$, calculating PRSs based on risk variants for a disorder identified in a $\mathrm{GWAS}^{27}$, and undertaking enrichment analysis to assess clustering of detected variants within functionally related genomic regions and biological pathways ${ }^{28}$.

To date, GWASs of OCD have not revealed any genome-wide significant SNPs associated with this disorder in case-control analyses $^{15}$. Recently, the Psychiatric Genomics Consortium OCD (PGC-OCD) workgroup combined data from the first two OCD GWASs ${ }^{29,30}$ to yield a sample of 2,688 OCD cases and 7,037 controls. The top-ranked detected SNP (i.e. strongest association) was in the $P=10^{-7}$ significance range ${ }^{31}$. Nonetheless, SNP-based heritability was estimated at $28 \%$ in this sample ${ }^{31}$, among the highest reported for neuropsychiatric disorders. These findings indicate the need for still larger samples for sufficient statistical power.

The top-ranked SNPs detected in the PGC-OCD GWAS were in linkage disequilibrium with genes previously associated with autism spectrum disorders (ASD) ${ }^{31}$ : GRID2, involved in cerebellar synaptic processes ${ }^{32}$, and KIT, implicated in neurodevelopment ${ }^{33}$. Moreover, a sex-stratified GWAS of the PGC-OCD sample revealed that SNPs with sex-specific effects were significantly enriched for genome regions influencing gene expression (i.e. expression quantitative trait loci, eQTLs) in brain and immune tissues ${ }^{34}$. In line with the findings of an earlier GWAS of obsessive-compulsive symptoms ${ }^{35}$, a recent meta-analysis of the PGC-OCD GWAS and a GWAS of

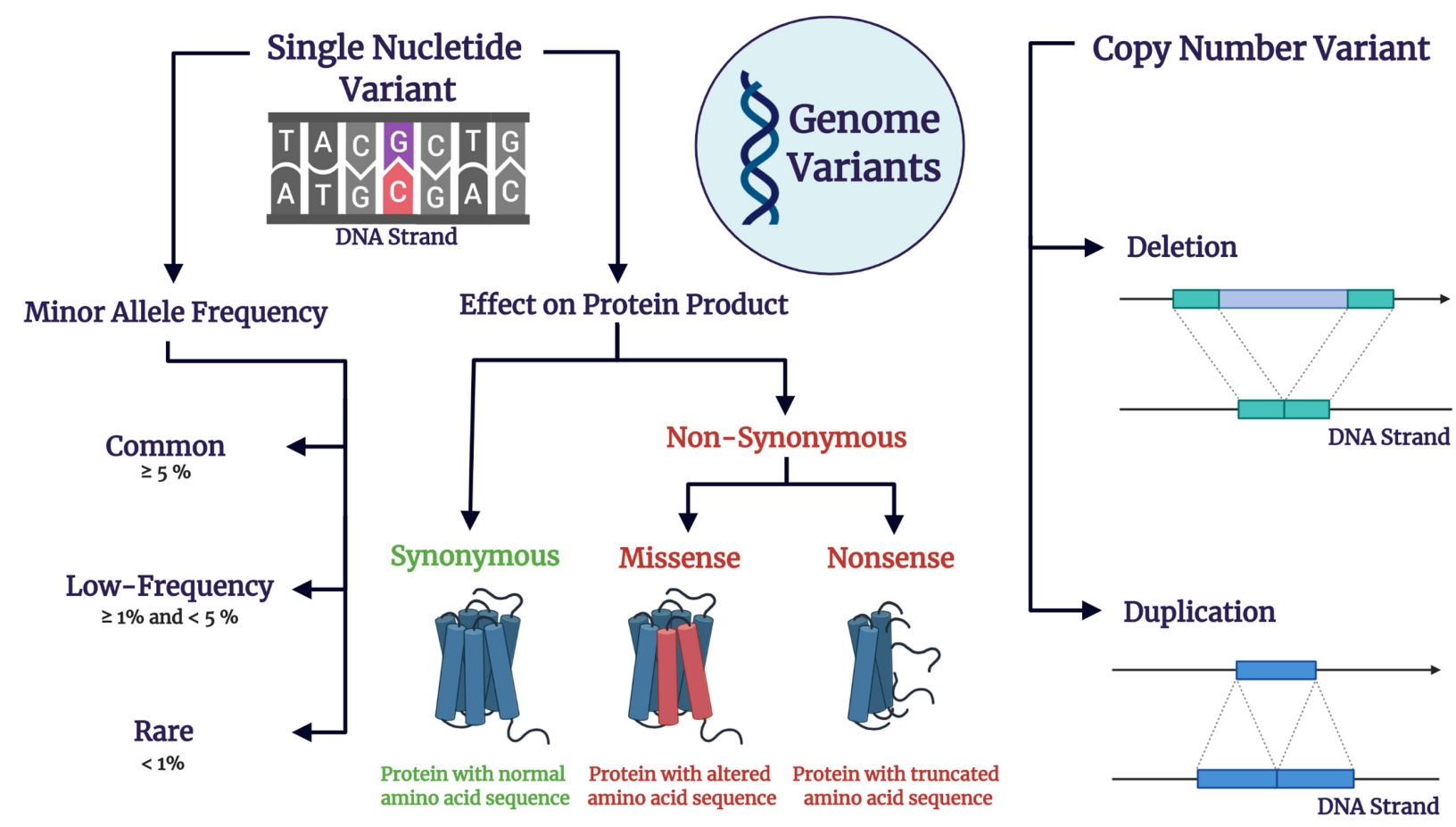

Figure 2. Variations in the genome. Single nucleotide variants (SNVs) constitute positions in the genome comprising a pair of bases for which different alleles (i.e. sequence variants) are found in a population. A SNV can be classified according to the frequency at which its second most common allele is found in a population, termed minor allele frequency (MAF). According to their MAF, SNVs can be classified into common (MAF $\geq 5 \%)$, low-frequency $(1 \% \geq M A F<5 \%)$, and rare $(M A F<1 \%)^{18}$. SNVs that occur in at least $1 \%$ of the population are called single nucleotide polymorphisms (SNPs) ${ }^{18}$. When occurring inside the exons (i.e. DNA stretches encoding protein products), SNVs can lead to the production of protein products with a normal amino acid sequence (i.e. synonymous SNVs), with an altered yet full amino acid sequence (i.e. missense SNVs), or with a truncated (i.e. incomplete) amino acid sequence (i.e. nonsense SNVs). The last two types of SNVs are termed nonsynonymous and usually have deleterious biological consequences. Copy number variants (CNVs) comprise genome deletions and duplications. 
compulsive symptoms in 8,267 nonclinical subjects revealed the most significant enrichment for genes expressed in brain regions associated with the neurocircuitry of OCD, i.e. the cingulate cortex, nucleus accumbens, and amygdala ${ }^{36}$. Taken together, the aforementioned GWASs suggest a role for synaptic, neurodevelopmental, and immune processes in the etiology of OCD.

Genetic correlation analyses using data from the PGC-OCD GWAS have suggested a shared genetic architecture between OCD and related conditions. In this respect, two studies found a significant genetic correlation between OCD and anorexia nervosa $(\mathrm{AN})^{37,38}$, consistent with the hypothesis that obsessive and compulsive traits in these conditions have shared etiology ${ }^{39}$. Furthermore, PRSs for other neuropsychiatric disorders were able to significantly predict case-control status in previous OCD GWAS samples, indicating a shared genetic liability ${ }^{40}$. In smaller studies, a PRS for schizophrenia (SCZ) significantly predicted case-control status in a Spanish sample comprising 370 OCD patients and 443 controls $^{41}$, and a PRS for ASD significantly predicted case-control status in a sample of 2,535 OCD cases and controls ${ }^{42}$. PRS may, in the future, have applications in clinical practice, ranging from improving diagnostic precision to predicting treatment response ${ }^{20}$. However, it needs to be emphasized that such applications are not currently possible and that translation of PRSs from a population of one ancestry to a population of different ancestry is problematic $^{43}$.

\section{Rare variants}

WES is a technique employed to detect single nucleotide variants in the exome (i.e. all of the genome exons) ${ }^{20}$, among which de novo variants (Figure 2) have the most pathogenic effect for neuropsychiatric disorders ${ }^{44}$. De novo variants refer to genome variants that occur in the proband but not in the parents. WES studies are usually performed in trios composed of healthy parents and an affected child in order to detect de novo variants driving pathology $\mathrm{y}^{20,44}$.

Two recent studies reported an increased genome-wide burden of gene-disrupting de novo mutations in patients with OCD. In the first WES study ${ }^{45}, 20$ nonsynonymous de novo variants were detected among 17 OCD probands at a rate similar to that reported for other neuropsychiatric disorders. Moreover, these variants were enriched for pathways related to the immune system and neurodevelopment.

The second WES study was conducted on a sample of 184 OCD and 777 control parent-child trios ${ }^{46}$. De novo damaging variants were significantly more frequent among probands, achieving a prevalence of $33.9 \%$. Such findings were used to estimate the rate of these variants among overall OCD cases at $22.2 \%$. Two high-confidence risk genes for OCD were further identified: $S C U B E 1$, potentially involved in endothelial inflammatory responses ${ }^{47}$, and $C H D 8$, implicated in chromatin metabolism ${ }^{48}$, neurogenesis ${ }^{49}$, and synaptic transmission ${ }^{50}$ and extensively associated with $\mathrm{ASD}^{51-53}$. Additionally, genes carrying de novo damaging variants in OCD probands significantly overlapped with genes associated with ASD, Tourette's syndrome (TS), and other neurodevelopmental disorders and were enriched for immune system pathways. Similar findings were reported in another study which found a significant overlap between genes associated with OCD and genes associated with ASD; in addition, the overlapping genes were significantly enriched for biological pathways related to brain function ${ }^{54}$.

\section{Copy number variants}

The most common type of structural variants in the human genome are CNVs (Figure 2), which comprise duplications and deletions ${ }^{55}$. The prevalence of CNVs can be assessed across the whole genome using array methods ${ }^{56}$.

In an earlier CNV study in OCD, a 4.4-fold increase in deletions encompassing loci associated with neurodevelopmental disorders (including 16p13.11) was found among OCD probands $^{57}$. More recently, two CNV studies were conducted on samples comprising 307 and 121 individuals with pediatric OCD and 3,861 and 124 healthy controls, respectively ${ }^{58,59}$. The number of CNVs in genes involved in brain function was higher among OCD probands in both studies. In the first study, CNVs were found in three targets of the fragile $\mathrm{X}$ mental retardation protein (FMRP). Consistent with FMRP involvement in several processes related to synaptic plasticity ${ }^{60}$ CNVs encompassing FMRP targets have been associated with $\mathrm{SCZ}^{61}$, $\mathrm{ASD}^{62}$, and attention deficit hyperactivity disorder (ADHD) ${ }^{63}$. In the second study, CNVs were found in genes implicated in SCZ, ASD, and TS. Finally, a recent study of 2,691 individuals diagnosed with OCD, SCZ, ASD, or ADHD found clinically relevant $\mathrm{CNVs}$ in $5.6 \%$ of OCD cases and multiple brain-expressed genes impacted by $\mathrm{CNVs}$ overlapping across those disorders ${ }^{64}$.

Taken together, these WES and CNV findings again support a role for synaptic, neurodevelopmental, and immune processes in the etiology of OCD. Moreover, these findings indicate the existence of a shared genetic etiology between OCD and related disorders, suggesting that their current diagnostic categories may not reflect distinct clinical entities. In line with this, a recent study used a machine learning approach to cluster patients with OCD, ASD, and ADHD into homogenous groups based on neuroimaging measures of cortical thickness and behavioral measures and found that those diagnostic categories were not reflected in the groups formed ${ }^{65}$.

\section{Variation in gene expression}

Complex regulatory mechanisms govern the way in which genotype and environment together lead to distinctive patterns of gene expression in different tissues at different developmental stages ${ }^{20,66,67}$. Methods are now available to explore tissue-specific gene expression and environmental regulatory mechanisms in OCD.

\section{Gene expression in specific tissue}

As a proxy of gene expression, the measurement of transcript levels (i.e. mRNA) (Figure 3) in post-mortem brain specimens 


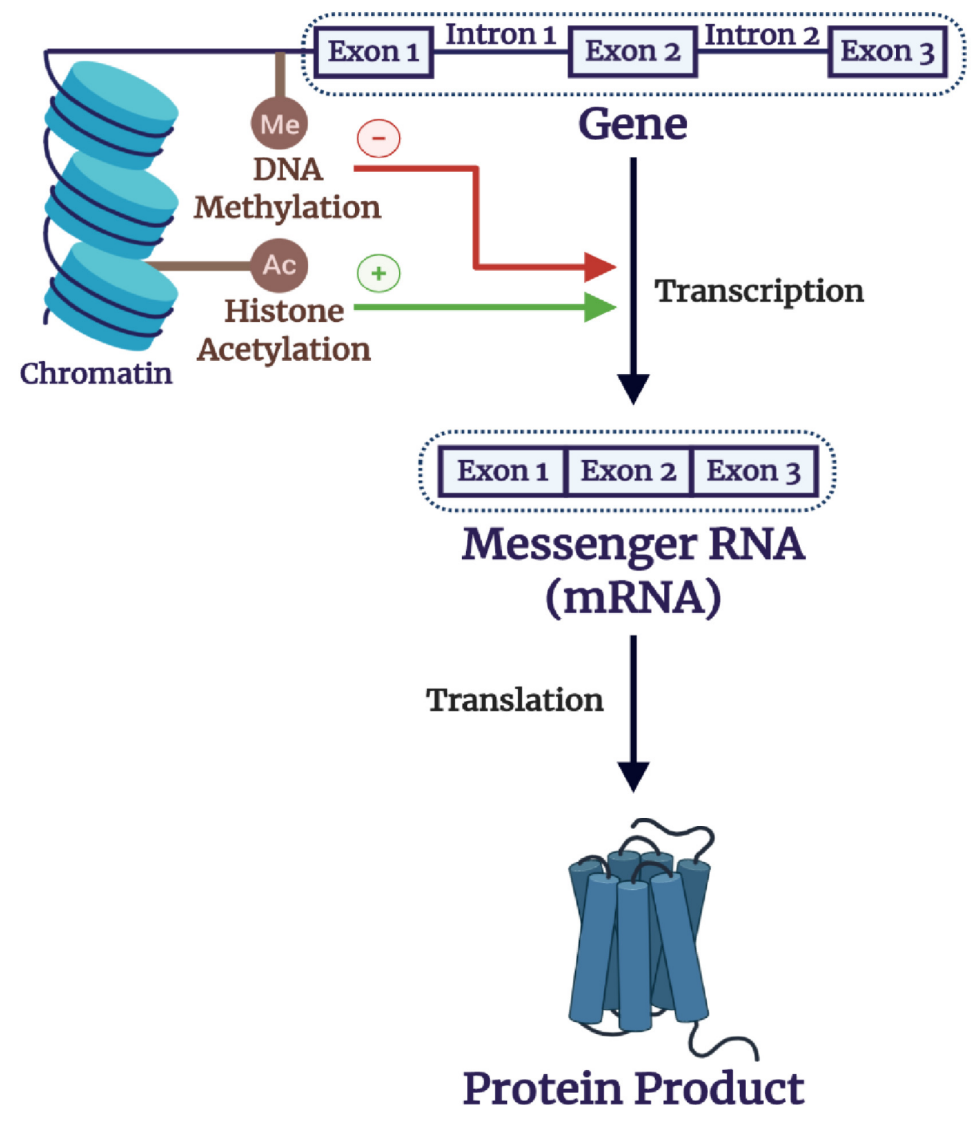

Figure 3. Gene expression. The gene, composed of exons (protein-coding regions) and introns (non-protein-coding regions), is transcribed into a precursor messenger ribonucleic acid (pre-mRNA), which undergoes alternative splicing to generate a messenger RNA (mRNA), called a primary transcript. Finally, mRNA undergoes translation to generate a protein product. This chain of events enables the flow of genetic information.

of patients with psychiatric disorders is useful for genetic investigations ${ }^{68}$. Furthermore, the discovery of differential transcript levels in the peripheral blood of patients with psychiatric disorders may provide additional insight into mechanisms underlying gene expression ${ }^{69}$.

Recently, reduced expression of genes related to excitatory glutamatergic synapses has been identified in the lateral and frontal regions of the orbitofrontal cortex (OFC) of individuals with $\mathrm{OCD}^{70}$. Speculatively, such findings may be relevant to understanding alterations in $\mathrm{OFC}$ volume $^{71}$ and activity in neuroimaging studies of $\mathrm{OCD}^{72}$.

Gene expression profiling in the peripheral blood has been employed to compare individuals with OCD, major depressive disorder (MDD), and SCZ and healthy controls ${ }^{73}$. A six-gene panel was able to diagnose OCD cases with $88 \%$ sensitivity and $85 \%$ specificity ${ }^{73}$. Among the genes included in the panel, FKBPIA encodes an enzyme involved in immune regulation ${ }^{74}$ and COPS7A encodes a subunit of a protein complex involved in protein degradation ${ }^{75}$.

\section{Gene expression and the environment}

The reciprocal interactions between gene expression and the environment have been investigated through diverse methods, ranging from basic science to epidemiological approaches ${ }^{76,77}$. Importantly, epigenetic mechanisms (Figure 3) provide a pathway whereby the environment can modulate gene expression through alterations in chromatin and DNA structure ${ }^{78}$.

In one recent study, no difference was found in blood DNA methylation levels of candidate genes previously implicated in OCD among 21 pediatric cases and 12 controls $^{79}$. Conversely, in another study using a genome-wide approach, multiple genes with different methylation levels were detected among 65 pediatric OCD cases and 96 controls $^{80}$. These findings emphasize the importance of an unbiased approach for studying the genomics of OCD.

A study of gene-environment interactions in a cohort of 103 patients with OCD revealed that neither PRS for OCD nor the presence of a stressful life event at the onset of the disorder predicted treatment response ${ }^{81}$. Nonetheless, PRS was able to 
predict illness severity. Moreover, environmental factors, such as perinatal complications ${ }^{82,83}$ and maternal effects (i.e. the influence of maternal genetic and environmental factors on the phenotype of the offspring $)^{84}$, have been shown to increase the risk for OCD. Further work is needed to determine whether PRSs, taken together with a range of environmental factors, may be useful in predicting OCD severity and treatment response. As a complement to the gene-environment interaction approach, in-depth environmental research in psychiatry, known as the exposome ${ }^{85}$, should add to the understanding of the interplay between genetics and the exposure to multiple internal and external stimuli in the prevention and treatment of psychiatric disorders.

\section{Modeling genetic architecture}

Laboratory-based experimental models may be used to study genes which appear to be important in clinical studies of the genomics of $\mathrm{OCD}^{86}$. We focus here on work done in animals and in human cells.

\section{Experimental animal systems}

Excessive grooming, hoarding behaviors (e.g. marble-burying), and stereotyped behaviors have been studied in rodent models of $\mathrm{OCD}^{87}$. Such work is not intended to replicate the disease in an animal system but may rather provide insight into the biological mechanisms relevant to OCD, which may foster the development of novel treatment approaches ${ }^{88}$.

Overexpression of the excitatory amino acid transporter 3 (EAAT3), involved in glutamate neurotransmission, in the frontal cortex, hippocampus, and striatum of rodents resulted in increasing grooming and disturbed cortical-striatal excitatory synapse plasticity ${ }^{89}$. Furthermore, a protective effect against the induction of stereotyped behaviors by dopaminergic challenge was obtained by constitutive EAAT3 reduced expression in mice ${ }^{90}$.

Immunity- and neuroinflammation-related processes have been consistently associated with $\mathrm{OCD}^{91}$. In this respect, mice with microglia-restricted progranulin inactivation exhibited increased self-grooming and marble-burying, which was normalized after suppression of nuclear factor $\kappa \mathrm{B}$ signaling in the microglia ${ }^{92}$. Also suggesting a potential role for the microglia in the etiology of OCD, targeted deletion of Hoxb8-lineage microglia yielded severe grooming, especially in female mice ${ }^{93}$. Furthermore, restoring tropomyosin receptor kinase B/ERK-MAPK signaling in mice normalized severe grooming behaviors induced by ablation of $S P R E D 2^{94}$, which pertain to a family of proteins that has been implicated in neurodevelopment ${ }^{95}$.

Recent investigations of gene pathway analysis ${ }^{96}$ and $\mathrm{PRSs}^{97}$ using GWAS data support the association of disturbances in insulin signaling with the pathophysiology of OCD. These findings were further validated in a rodent model of type 2 diabetes mellitus, which revealed increased compulsive-like behaviors and brain abnormalities previously associated with $\mathrm{OCD}^{98}$
Findings from experimental animal systems may inform clinical studies ${ }^{99}$. A large set of candidate genes potentially associated with OCD in previous human, rodent, and canine studies was investigated using a target-sequencing approach for the detection of regulatory and coding variants (i.e. functional variants) in 592 OCD cases and 560 controls $^{100}$. Among the four genes significantly enriched for functional variants in OCD cases (i.e. NRXN1, HTR2A, CTTNBP2, and REEP3), all were involved in brain biological pathways implicated in $\mathrm{OCD}^{100}$. Additionally, NRXN1 achieved genome-wide significance when OCD cases were compared to 33,370 controls $^{100}$.

\section{Human cell models}

Investigations using human-derived cells as models may be useful in studying OCD at the molecular and cellular levels ${ }^{101}$. Higher ratios of immune cells in the peripheral blood ${ }^{102,103}$ and abnormal production of inflammatory cytokines upon stimulation by those cells ${ }^{102}$ have been reported in OCD. Future work on pluripotent stem cells derived from somatic cells of patients with OCD could be useful in extending this preliminary work.

\section{Genetic variations underlying relevant phenotypes}

There is growing interest in determining the genetic basis of OCD-associated neuroimaging abnormalities, cognitive dysfunction, and treatment response, as outlined below.

\section{Neuroimaging}

The Enhancing Neuroimaging Genetics through Meta-Analysis (ENIGMA) consortium is the largest collaboration working to integrate genetic and neuroimaging findings; it combines findings from sites across the globe ${ }^{104}$. The combination of data from the first OCD GWAS and the ENIGMA GWAS of subcortical brain structure $^{105}$ allowed for the detection of a significant overlap between the SNPs associated with increases in the risk for OCD and in the volumes of the putamen, a component of the cortical-striatal-thalamic-cortical circuitry implicated in $\mathrm{OCD}^{106}$, and the nucleus accumbens, a treatment target for deep brain stimulation in treatment-refractory $\mathrm{OCD}^{107}$. Moreover, the SNP associated with both the increased risk for OCD and the increased putamen volume is located near the RSPO4, a gene implicated in pathways related to neurodevelopment ${ }^{108}$.

\section{Cognitive dysfunction}

Cognitive deficits have been frequently explored as OCD endophenotypes ${ }^{109}$, defined as heritable quantitative traits found at higher rates in unaffected relatives of patients and associated with increased genetic susceptibility to the disorder ${ }^{10,111}$. The findings of investigations on cognitive deficits as endophenotypes of OCD have been recently meta-analyzed ${ }^{112}$; this study found significant impairment in global executive functioning among unaffected relatives, with specific deficits in planning, visuospatial working memory, and verbal fluency. Since these endophenotypes may be more proximally related to genetic mechanisms than OCD itself $^{111}$, further investigation of these deficits may be useful. 


\section{Treatment response}

Pharmacogenetic studies address the association of genetic variation with drug response ${ }^{113}$. Although earlier pharmacogenetic studies in psychiatric disorders have focused mainly on candidate genes and on genes related to the cytochrome P450 system $^{114}$, genome-wide approaches have been recently employed in OCD research.

The association of the response to serotonin reuptake inhibitors (SRIs) treatment with common variants was assessed in a GWAS of 804 OCD cases, including 514 responders and 290 non-responders ${ }^{115}$. A genome-wide significant SNP was detected near the gene DISP1, within a chromosomal region associated with neurodevelopment. Further enrichment analysis revealed that the most significant SNPs were enriched for biological pathways related to glutamate and serotonin neurotransmission. However, a follow-up study with 112 OCD cases found no association between the SNP located near DISP1 and the response to SRIs treatment ${ }^{116}$. Further investigation in larger samples is warranted to determine the clinical utility of pharmacogenetic data in OCD.

\section{OCD genetic architecture: an exploratory model}

The data described in the previous sections suggest that genes involved in synaptic transmission, neurodevelopment, and the immune and inflammatory systems are involved in the pathophysiology of OCD (Figure 1). Based on these data, an exploratory analysis was undertaken with GeneNets in order to investigate whether genes associated with risk for OCD, identified in studies assessing common and rare variants, would form communities (i.e. clusters of functionally connected genes involved in a particular biological process $)^{117}$. Three communities were significantly enriched for biological processes: related to glutamate neurotransmission, to cell adhesion, and to the immune system (Figure 4). These findings are consistent with a model in which multiple genes and biological pathways play a role in the pathogenesis of OCD and in which synaptic, neurodevelopmental, and immune pathways may be particularly important.

\section{OCD genetics: current insights and future prospects}

This review shows how several recent developments in genomics have contributed to understanding the genetic architecture of OCD. The use of cutting-edge methods has moved the field from a focus on candidate genes in underpowered samples to unbiased approaches in larger cohorts. At the same time, a great deal more work is needed to fully understand the role of common and rare gene variants in OCD. Work on gene methylation and expression has provided proof-of-principle demonstrations of the value of such studies and deserves expansion. Such work, taken together with careful phenotyping and comparison of individuals with different disorders, may lead to a better understanding of transdiagnostic genetic mechanisms.

The question of how advances in the genomics of OCD will become clinically useful remains to be answered. First-line pharmacological treatments for OCD target mostly serotonergic neurotransmission; biological pathways implicated in recent
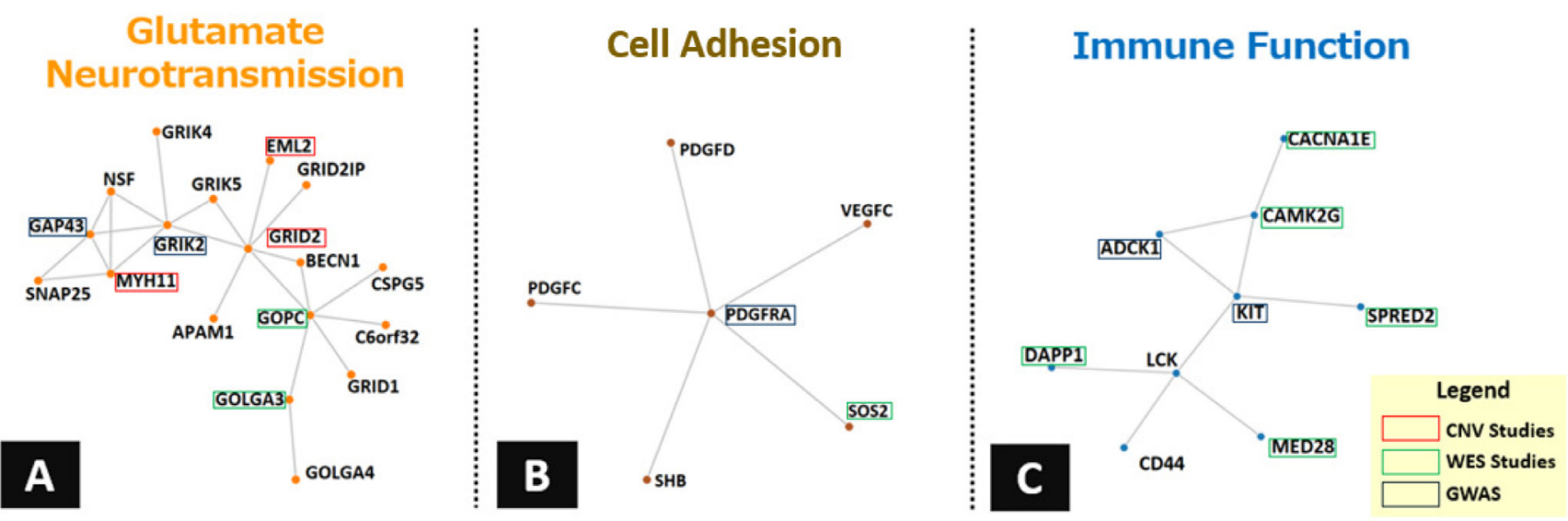

Figure 4. Gene networks exploratory analysis. The GeneNets algorithm was used to ascertain whether a set of obsessive-compulsive disorder (OCD) risk genes were more significantly connected to each other in a functional network as would be expected by chance alone. Accordingly, a total of 204 OCD-associated genes were selected from studies cited throughout the present review (more specifically, seven genome-wide association studies [GWASs] ${ }^{29-31,35,36,41,42}$, two whole-exome sequencing [WES] studies ${ }^{45,46}$, two copy number variant [CNV] studies $^{58,59}$, and one functional variants study ${ }^{100}$ ) for the GeneNets exploratory analysis. A total of 125 of these genes were included in a significant network, in which three communities were enriched for biological pathways. More specifically, the most significant pathways detected for those communities were the ionotropic activity of kainate receptors $\left(P<10^{-6}\right)$, associated with glutamate neurotransmission ${ }^{118}$ (Figure 4A); the cell adhesion-related processes $\left(P<10^{-9}\right)$, involved in synaptic processes ${ }^{119}$ and neurodevelopment ${ }^{120,121}($ Figure $4 \mathrm{~B})$; the regulation of kit signaling $\left(P<10^{-4}\right)$, associated with immune function ${ }^{122}$ (Figure $\left.4 \mathrm{C}\right)$; and the activation of GABAA receptors $\left(P<10^{-12}\right)$, implicated in neuropsychiatric disorders ${ }^{123}$. For the pathways displayed in the figure, the type of study from which their respective genes were selected is highlighted in the figure. 
genomic studies, such as those related to glutamatergic, neurodevelopmental, and the immune and inflammatory systems, may be useful targets in the future. More robust pharmacogenetic evidence may ultimately improve the prediction of response to pharmacological treatments, advancing precision medicine for OCD. Shared genetic liability among OCD, ASD, and SCZ may suggest new approaches to transdiagnostic assessment of patients. That said, to date, genetic studies have not demonstrated clinical utility, suggesting that OCD is not a simple homogeneous entity but rather that the underlying biological pathways are complex, variable, and heterogeneous. We can expect that translation from bench to bedside, through continuous effort and collaborative work, will ultimately transform our understanding of what causes OCD and thus how best to treat it.
1. American Psychiatric Association: Diagnostic and statistical manual of menta disorders. 5th ed. 2013

Publisher Full Tex

2. Fontenelle LF, Mendlowicz MV, Versiani M: The descriptive epidemiology of obsessive-compulsive disorder. Prog Neuropsychopharmacol Biol Psychiatry. 2006; 30(3): 327-37.

PubMed Abstract | Publisher Full Text

3. Ruscio AM, Stein DJ, Chiu WT, et al.: The epidemiology of obsessivecompulsive disorder in the National Comorbidity Survey Replication. $\mathrm{Mol}$ Psychiatry. 2010; 15(1): 53-63.

PubMed Abstract | Publisher Full Text | Free Full Text |

Faculty Opinions Recommendation

4. Subramaniam M, Soh P, Vaingankar JA, et al.: Quality of life in obsessivecompulsive disorder: impact of the disorder and of treatment. CNS Drugs. 2013; 27(5): 367-83.

PubMed Abstract | Publisher Full Text

5. Torres AR, Prince MJ, Bebbington PE, et al:: Obsessive-compulsive disorder: prevalence, comorbidity, impact, and help-seeking in the British National Psychiatric Morbidity Survey of 2000. Am J Psychiatry. 2006; 163(11): 1978-85. PubMed Abstract | Publisher Full Text

6. Meier SM, Mattheisen M, Mors O, et al.: Mortality Among Persons With Obsessive-Compulsive Disorder in Denmark. JAMA Psychiatry. 2016; 73(3): 268-74.

PubMed Abstract | Publisher Full Text | Free Full Text

7. Hirschtritt ME, Bloch MH, Mathews CA: Obsessive-Compulsive Disorder: Advances in Diagnosis and Treatment. JAMA. 2017; 317(13): 1358-67. PubMed Abstract | Publisher Full Text

8. Erzegovesi S, Cavallini MC, Cavedini P, et al.: Clinical predictors of drug response in obsessive-compulsive disorder. J Clin Psychopharmacol. 2001; 21(5): 488-92.

PubMed Abstract | Publisher Full Text

9. Guo SW: Familial aggregation of environmental risk factors and familial aggregation of disease. Am J Epidemiol. 2000; 151(11): 1121-31. PubMed Abstract | Publisher Full Text

10. Pauls DL, Alsobrook JP 2nd, Goodman W, et al:: A family study of obsessivecompulsive disorder. Am J Psychiatry. 1995; 152(1): 76-84. PubMed Abstract | Publisher Full Text

11. do Rosario-Campos MC, Leckman JF, Curi M, et al: A family study of early-onset obsessive-compulsive disorder. Am J Med Genet B Neuropsychiatr Genet 2005; 136B(1): 92-7.

PubMed Abstract | Publisher Full Text

12. Mataix-Cols $\mathrm{D}$, Boman M, Monzani B, et al.: Population-based, multigenerationa family clustering study of obsessive-compulsive disorder. JAMA Psychiatry. 2013; 70(7): 709-17. PubMed Abstract | Publisher Full Text

13. Brander G, Kuja-Halkola R, Rosenqvist MA, et al.: A population-based family clustering study of tic-related obsessive-compulsive disorder. Mol Psychiatry. 2019.

PubMed Abstract | Publisher Full Text | Faculty Opinions Recommendation

14. Visscher PM, Hill WG, Wray NR: Heritability in the genomics era--concepts and misconceptions. Nat Rev Genet. 2008; 9(4): 255-66. PubMed Abstract | Publisher Full Text

15. Zai G, Barta $C$, Cath $D$, et al:: New insights and perspectives on the genetics of obsessive-compulsive disorder. Psychiatr Genet. 2019; 29(5): 142-51. PubMed Abstract | Publisher Full Text trait dimensions in youth from the general population. Transl Psychiatry. 2018; 8(1): 191.

PubMed Abstract | Publisher Full Text | Free Full Text |

Faculty Opinions Recommendation

17. Ramamoorthy A, Yee SW, Karnes J: Unveiling the Genetic Architecture of Human Disease for Precision Medicine. Clin Trans/ Sci. 2019; 12(1): 3-5. PubMed Abstract | Publisher Full Text | Free Full Text

18. Timpson NJ, Greenwood CMT, Soranzo N, et al:: Genetic architecture: the shape of the genetic contribution to human traits and disease. Nat Rev Genet. 2018; 19(2): 110-24.

PubMed Abstract | Publisher Full Text

19. Duncan LE, Ostacher M, Ballon J: How genome-wide association studies (GWAS) made traditional candidate gene studies obsolete. Neuropsychopharmacology. 2019; 44(9): 1518-23. PubMed Abstract | Publisher Full Text | Free Full Text

20. Sullivan PF, Geschwind DH: Defining the Genetic, Genomic, Cellular, and Diagnostic Architectures of Psychiatric Disorders. Cell. 2019; 177(1): 162-83. PubMed Abstract | Publisher Full Text | Free Full Text | Faculty Opinions Recommendation

21. Horwitz $\mathrm{T}$, Lam $\mathrm{K}$, Chen $\mathrm{Y}$, et al.: A decade in psychiatric GWAS research. Mol Psychiatry. 2019; 24(3): 378-89. PubMed Abstract | Publisher Full Text | Free Full Text

22. Fadista J, Manning AK, Florez JC, et al.: The (in)famous GWAS $P$-value threshold revisited and updated for low-frequency variants. Eur J Hum Genet. 2016; 24(8) 1202-5.

PubMed Abstract | Publisher Full Text | Free Full Text

23. Collins AL, Sullivan PF: Genome-wide association studies in psychiatry: what have we learned? Br J Psychiatry. 2013; 202(1): 1-4. PubMed Abstract | Publisher Full Text | Free Full Text

24. Yang J, Zeng J, Goddard ME, et al:: Concepts, estimation and interpretation of SNP-based heritability. Nat Genet. 2017; 49(9): 1304-10. PubMed Abstract | Publisher Full Text

25. Zhang Z, Ma P, Li Q, et al:: Exploring the Genetic Correlation Between Growth and Immunity Based on Summary Statistics of Genome-Wide Association Studies. Front Genet. 2018; 9: 393. PubMed Abstract | Publisher Full Text | Free Full Text | Faculty Opinions Recommendation

26. van Rheenen W, Peyrot WJ, Schork AJ, et al:: Genetic correlations of polygenic disease traits: from theory to practice. Nat Rev Genet. 2019; 20(10): 567-81. PubMed Abstract | Publisher Full Text

27. Duncan L, Shen H, Gelaye B, et al.: Analysis of polygenic risk score usage and performance in diverse human populations. Nat Commun. 2019; 10(1): 3328. PubMed Abstract | Publisher Full Text | Free Full Text

28. Reimand $\mathrm{J}$, Isserlin $\mathrm{R}$, Voisin $\mathrm{V}$, et al.: Pathway enrichment analysis and visualization of omics data using g:Profiler, GSEA, Cytoscape and EnrichmentMap. Nat Protoc. 2019; 14(2): 482-517. PubMed Abstract | Publisher Full Text | Free Full Text

29. Stewart SE, Yu D, Scharf JM, et al:: Genome-wide association study of obsessive-compulsive disorder. Mol Psychiatry. 2013; 18(7): 788-98. PubMed Abstract | Publisher Full Text | Free Full Text

30. Mattheisen M, Samuels JF, Wang Y, et al:: Genome-wide association study in obsessive-compulsive disorder: results from the OCGAS. Mol Psychiatry. 2015; 20(3): 337-44 PubMed Abstract | Publisher Full Text | Free Full Text

31. International Obsessive Compulsive Disorder Foundation Genetics Collaborative (IOCDF-GC) and OCD Collaborative Genetics Association Studies 
(OCGAS): Revealing the complex genetic architecture of obsessivecompulsive disorder using meta-analysis. Mol Psychiatry. 2018; 23(5): 1181-8. PubMed Abstract | Publisher Full Text | Free Full Text Faculty Opinions Recommendation

32. Yuzaki M: Cerebellar LTD vs. motor learning-lessons learned from studying GluD2. Neural Netw. 2013; 47: 36-41. PubMed Abstract | Publisher Full Text

33. Aoki H, Hara A, Kunisada T: Induced haploinsufficiency of Kit receptor tyrosine kinase impairs brain development. JCl Insight. 2017; 2(19): e94385. PubMed Abstract | Publisher Full Text | Free Full Text

34. Khramtsova EA, Heldman R, Derks EM, et al:: Sex differences in the genetic architecture of obsessive-compulsive disorder. Am J Med Genet B Neuropsychiatr Genet. 2019; 180(6): 351-64. PubMed Abstract | Publisher Full Text | Free Full Text Faculty Opinions Recommendation

35. den Braber A, Zilhão NR, Fedko IO, et al:: Obsessive-compulsive symptoms in a large population-based twin-family sample are predicted by clinically based polygenic scores and by genome-wide SNPs. Transl Psychiatry. 2016; 6(2): e731.

PubMed Abstract | Publisher Full Text | Free Full Text

36. S Smit DJA, Cath D, Zilhão NR, et al:: Genetic meta-analysis of obsessivecompulsive disorder and self-report compulsive symptoms. Am J Med Genet B Neuropsychiatr Genet. 2020; 183(4): 208-216. PubMed Abstract | Publisher Full Text | Free Full Text | Faculty Opinions Recommendation

37. Cross-Disorder Group of the Psychiatric Genomics Consortium: Genomic Relationships, Novel Loci, and Pleiotropic Mechanisms across Eight Psychiatric Disorders. Cell. 2019; 179(7): 1469-1482.e11. PubMed Abstract | Publisher Full Text | Free Full Text | Faculty Opinions Recommendation

38. Anttila V, Bulik-Sullivan B, Finucane HK, et al.: Analysis of shared heritability in common disorders of the brain. Science. 2018; 360(6395): eaap8757. PubMed Abstract | Publisher Full Text | Free Full Text Faculty Opinions Recommendation

39. Allen A, King A, Hollander E: Obsessive-compulsive spectrum disorders. Dialogues Clin Neurosci. 2003; 5(3): 259-71. PubMed Abstract | Free Full Text

40. McIntosh AM, Sullivan PF, Lewis CM: Uncovering the Genetic Architecture of Major Depression. Neuron. 2019; 102(1): 91-103. PubMed Abstract | Publisher Full Text | Free Full Text Faculty Opinions Recommendation

41. Costas J, Carrera N, Alonso P, et al.: Exon-focused genome-wide association study of obsessive-compulsive disorder and shared polygenic risk with schizophrenia. Transl Psychiatry. 2016; 6(3): e768. PubMed Abstract | Publisher Full Text | Free Full Text

42. Guo W, Samuels JF, Wang Y, et al:: Polygenic risk score and heritability estimates reveals a genetic relationship between ASD and OCD. Eur Neuropsychopharmacol. 2017; 27(7): 657-666. PubMed Abstract | Publisher Full Text

43. Martin AR, Gignoux CR, Walters RK, et al:: Human Demographic History Impacts Genetic Risk Prediction across Diverse Populations. Am J Hum Genet. 2017 100(4): 635-649.

PubMed Abstract | Publisher Full Text | Free Full Text

44. Wang W, Corominas R, Lin GN: De novo Mutations From Whole Exome Sequencing in Neurodevelopmental and Psychiatric Disorders: From Discovery to Application. Front Genet. 2019; 10: 258 PubMed Abstract | Publisher Full Text | Free Full Text Faculty Opinions Recommendation

45. Cappi $\mathrm{C}$, Brentani H, Lima L, et al:: Whole-exome sequencing in obsessivecompulsive disorder identifies rare mutations in immunological and neurodevelopmental pathways. Transl Psychiatry. 2016; 6(3): e764 PubMed Abstract | Publisher Full Text | Free Full Text

46. Cappi C, Oliphant ME, Péter Z, Zai G, et al.: De Novo Damaging DNA Coding Mutations Are Associated With Obsessive-Compulsive Disorder and Overlap With Tourette's Disorder and Autism. Biol Psychiatry. 2020; 87(12): 1035-1044. PubMed Abstract | Publisher Full Text | Free Full Text

47. Yang RB, Ng CKD, Wasserman SM, et al.: Identification of a novel family of cellsurface proteins expressed in human vascular endothelium. J Biol Chem. 2002; 277(48): 46364-73

PubMed Abstract | Publisher Full Tex

48. Ronan JL, Wu W, Crabtree GR: From neural development to cognition: Unexpected roles for chromatin. Nat Rev Genet. 2013; 14(5): 347-59. PubMed Abstract | Publisher Full Text | Free Full Text

49. Durak O, Gao F, Kaeser-Woo YJ, et al:: Chd8 mediates cortical neurogenesis via transcriptional regulation of cell cycle and Wnt signaling. Nat Neurosci. 2016; 19(11): 1477-1488.

PubMled Abstract | Publisher Full Text | Free Full Text |

Faculty Opinions Recommendation
50. Jung $\mathrm{H}$, Park $\mathrm{H}, \mathrm{Choi} \mathrm{Y}$, et al:: Sexually dimorphic behavior, neuronal activity, and gene expression in Chd8-mutant mice. Nat Neurosci. 2018; 21 $1218-28$

PubMed Abstract | Publisher Full Text | Faculty Opinions Recommendation

51. $\mathrm{Xu} Q$, Liu YY, Wang $X$, et al:: Autism-associated CHD8 deficiency impairs axon development and migration of cortical neurons. Mol Autism. 2018; 9: 65. PubMed Abstract | Publisher Full Text | Free Full Text

52. Yasin H, Gibson WT, Langlois S, et al.: A distinct neurodevelopmental syndrome with intellectual disability, autism spectrum disorder, characteristic facies, and macrocephaly is caused by defects in CHD8. J Hum Genet. 2019; 64(4): 271-80

PubMed Abstract | Publisher Full Text | Faculty Opinions Recommendation

53. Kita $Y$, Katayama $Y$, Shiraishi T, et al:: The Autism-Related Protein CHD8 Cooperates with C/EBP $\beta$ to Regulate Adipogenesis. Cell Rep. 2018; 23(7): 1988-2000. PubMed Abstract | Publisher Full Text

54. Liu D, Cao H, Kural KC, et al.: Integrative analysis of shared genetic pathogenesis by autism spectrum disorder and obsessive-compulsive disorder. Biosci Rep. 2019; 39(12): BSR20191942. PubMed Abstract | Publisher Full Text | Free Full Text | Faculty Opinions Recommendation

55. McCarroll SA, Altshuler DM: Copy-number variation and association studies of human disease. Nat Genet. 2007; 39(7 Suppl): S37-42. PubMed Abstract | Publisher Full Text

56. Levy RJ, Xu B, Gogos JA, et al.: Copy number variation and psychiatric disease risk. Methods Mol Biol. 2012; 838: 97-113. PubMed Abstract | Publisher Full Text

57. McGrath LM, Yu D, Marshall C, et al:: Copy number variation in obsessivecompulsive disorder and tourette syndrome: A cross-disorder study. J Am Acad Child Adolesc Psychiatry. 2014; 53(8): 910-9. PubMed Abstract | Publisher Full Text | Free Full Text

58. Gazzellone MJ, Zarrei M, Burton CL, et al.: Uncovering obsessive-compulsive disorder risk genes in a pediatric cohort by high-resolution analysis of copy number variation. J Neurodev Disord. 2016; 8: 36 PubMed Abstract | Publisher Full Text | Free Full Text

59. Grünblatt $\mathrm{E}$, Oneda $\mathrm{B}$, Ekici $\mathrm{AB}$, et al:: High resolution chromosomal microarray analysis in paediatric obsessive-compulsive disorder. BMC Med Genomics. 2017; 10(1): 68 PubMed Abstract | Publisher Full Text | Free Full Text

60. Prieto M, Folci A, Martin S: Post-translational modifications of the Fragile $\mathrm{X}$ Mental Retardation Protein in neuronal function and dysfunction. $\mathrm{Mol}$ Psychiatry. 2020; 25(8): 1688-1703. PubMed Abstract | Publisher Full Text

61. Szatkiewicz JP, O'Dushlaine C, Chen G, et al:: Copy number variation in schizophrenia in Sweden. Mol Psychiatry. 2014; 19(7): 762-73. PubMed Abstract | Publisher Full Text | Free Full Text

62. Pinto $D$, Delaby $E$, Merico $D$, et al.: Convergence of genes and cellular pathways dysregulated in autism spectrum disorders. Am J Hum Genet. 2014; 94: 677-94. PubMed Abstract | Publisher Full Text | Free Full Text

63. Thapar A, Martin J, Mick E, et al.: Psychiatric gene discoveries shape evidence on ADHD's biology. Mol Psychiatry. 2016; 21(9): 1202-7. PubMed Abstract | Publisher Full Text | Free Full Text

64. Zarrei M, Burton CL, Engchuan W, et al.: A large data resource of genomic copy number variation across neurodevelopmental disorders. NPJ Genom Med. 2019; 4: 26

PubMed Abstract | Publisher Full Text | Free Full Text | Faculty Opinions Recommendation

65. Kushki A, Anagnostou E, Hammill C, et al.: Examining overlap and homogeneity in ASD, ADHD, and OCD: a data-driven, diagnosis-agnostic approach. Transl Psychiatry. 2019; 9(1): 318.

PubMed Abstract | Publisher Full Text | Free Full Text | Faculty Opinions Recommendation

66. Tung J, Gilad Y: Social environmental effects on gene regulation. Cell Mol Life Sci. 2013; 70(22): 4323-39. PubMed Abstract | Publisher Full Text | Free Full Text

67. Smith M, Flodman PL: Expanded Insights Into Mechanisms of Gene Expression and Disease Related Disruptions. Front Mol Biosci. 2018; 5: 101. PubMed Abstract | Publisher Full Text | Free Full Text

68. Guan J, Cai JJ, Ji G, et al.: Commonality in dysregulated expression of gene sets in cortical brains of individuals with autism, schizophrenia, and bipolar disorder. Transl Psychiatry. 2019; 9(1): 152 PubMed Abstract | Publisher Full Text | Free Full Text | Faculty Opinions Recommendation

69. Frésard L, Smail C, Ferraro NM, et al.: Identification of rare-disease genes using blood transcriptome sequencing and large control cohorts. Nat Med. 2019; 25(6): 911-919.

PubMed Abstract | Publisher Full Text | Free Full Text |

Faculty Opinions Recommendation 
70. Piantadosi SC, Chamberlain BL, Glausier JR, et al.: Lower excitatory synaptic gene expression in orbitofrontal cortex and striatum in an initial study of subjects with obsessive compulsive disorder. Mol Psychiatry. 2019. PubMed Abstract | Publisher Full Text | Faculty Opinions Recommendation

71. Rotge JY, Guehl D, Dilharreguy B, et al:: Meta-analysis of brain volume changes in obsessive-compulsive disorder. Biol Psychiatry. 2009; 65(1): 75-83. PubMed Abstract | Publisher Full Text

72. Menzies L, Chamberlain SR, Laird AR, et al.: Integrating evidence from neuroimaging and neuropsychological studies of obsessive-compulsive disorder: The orbitofronto-striatal model revisited. Neurosci Biobehav Rev. 2008; 32(3): 525-49.

PubMed Abstract | Publisher Full Text | Free Full Text

73. W Wang $\mathrm{Y}, \mathrm{Cheng} \mathrm{C}$, Zhang $\mathrm{Z}$, et al.: Blood-based dynamic genomic signature for obsessive-compulsive disorder. Am J Med Genet B Neuropsychiatr Genet. 2018; 177(8): 709-16.

PubMed Abstract | Faculty Opinions Recommendation

74. Kang $\mathrm{CB}$, Hong $\mathrm{Y}$, Dhe-Paganon S, et al.: FKBP family proteins: Immunophilins with versatile biological functions. Neurosignals. 2008; 16(4): 318-25. PubMed Abstract | Publisher Full Text

75. Berse $M$, Bounpheng $M$, Huang $X$, et al:: Ubiquitin-dependent degradation of Id1 and Id3 is mediated by the COP9 signalosome. J Mol Biol. 2004; 343(2): 361-70. PubMed Abstract | Publisher Full Text

76. Schmitt A, Malchow B, Hasan A, et al:: The impact of environmental factors in severe psychiatric disorders. Front Neurosci. 2014; 8: 19 PubMed Abstract | Publisher Full Text | Free Full Text

77. Idaghdour $\mathrm{Y}$, Awadalla $\mathrm{P}$ : Exploiting gene expression variation to capture gene-environment interactions for disease. Front Genet. 2012; 3: 228. PubMed Abstract | Publisher Full Text | Free Full Text

78. Ptak C, Petronis A: Epigenetic approaches to psychiatric disorders. Dialogues Clin Neurosci. 2010; 12(1): 25-35.

PubMed Abstract | Publisher Full Text | Free Full Text

79. Nissen JB, Hansen CS, Starnawska A, et al.: DNA Methylation at the Neonatal State and at the Time of Diagnosis: Preliminary Support for an Association with the Estrogen Receptor 1, Gamma-Aminobutyric Acid B Receptor 1, and Myelin Oligodendrocyte Glycoprotein in Female Adolescent Patients with OCD. Front Psychiatry. 2016; 7: 35

PubMed Abstract | Publisher Full Text | Free Full Text

80. Yue W, Cheng W, Liu Z, et al:: Genome-wide DNA methylation analysis in obsessive-compulsive disorder patients. Sci Rep. 2016; 6: 31333. PubMed Abstract | Publisher Full Text | Free Full Text

81. Alemany-Navarro M, Costas J, Real E, et al.: Do polygenic risk and stressful life events predict pharmacological treatment response in obsessive compulsive disorder? A gene-environment interaction approach. Trans Psychiatry. 2019; 9(1): 70

PubMed Abstract | Publisher Full Text | Free Full Text Faculty Opinions Recommendation

82. Brander G, Pérez-Vigil A, Larsson $\mathrm{H}$, et al.: Systematic review of environmental risk factors for Obsessive-Compulsive Disorder: A proposed roadmap from association to causation. Neurosci Biobehav Rev. 2016; 65: 36-62. PubMed Abstract | Publisher Full Text

83. Brander G, Rydell M, Kuja-Halkola R, et al.: Association of Perinatal Risk Factors With Obsessive-Compulsive Disorder: A Population-Based Birth Cohort, Sibling Control Study. JAMA Psychiatry. 2016; 73(11): 1135-44. PubMed Abstract | Publisher Full Text

84. Mahjani B, Klei L, Hultman CM, et al.: Maternal Effects as Causes of Risk for Obsessive-Compulsive Disorder. Biol Psychiatry. 2020; 87(12): 1045-51. PubMed Abstract | Publisher Full Text | Faculty Opinions Recommendation

85. Guloksuz S, van Os J, Rutten BPF: The Exposome Paradigm and the Complexities of Environmental Research in Psychiatry. JAMA Psychiatry. 2018; 75(10): 985-6.

PubMed Abstract | Publisher Full Text

86. Dourlen P, Chapuis J, Lambert JC: Using High-Throughput Animal or Cell-Based Models to Functionally Characterize GWAS Signals. Curr Genet Med Rep. 2018; 6(3): 107-15.

PubMed Abstract | Publisher Full Text | Free Full Text

87. Grados M, Prazak M, Saif A, et al:: A review of animal models of obsessive-compulsive disorder: A focus on developmental, immune, endocrine and behavioral models. Expert Opin Drug Discov. 2016; 11(1): 27-43. PubMed Abstract | Publisher Full Text

88. Scherma M, Giunti E, Fratta W, et al.: Gene knockout animal models of depression, anxiety and obsessive compulsive disorders. Psychiatr Genet. 2019; 29(5): 191-9. PubMed Abstract | Publisher Full Text

89. Delgado-Acevedo C, Estay SF, Radke AK, et al:: Behavioral and synaptic alterations relevant to obsessive-compulsive disorder in mice with increased EAAT3 expression. Neuropsychopharmacology. 2019; 44(6): 1163-73. PubMed Abstract | Publisher Full Text | Free Full Text Faculty Opinions Recommendation
90. Zike ID, Chohan MO, Kopelman JM, et al:: OCD candidate gene SLC1A1/EAAT3 impacts basal ganglia-mediated activity and stereotypic behavior. Proc Natl Acad Sci U S A. 2017; 114(22): 5719-24.

PubMed Abstract | Publisher Full Text | Free Full Text

91. Gerentes M, Pelissolo A, Rajagopal K, et al.: Obsessive-Compulsive Disorder: Autoimmunity and Neuroinflammation. Curr Psychiatry Rep. 2019; 21(8): 78. PubMed Abstract | Publisher Full Text

92. Krabbe G, Minami SS, Etchegaray Jl, et al.: Microglial NFKB-TNF $\alpha$ hyperactivation induces obsessive-compulsive behavior in mouse models of progranulin-deficient frontotemporal dementia. Proc Natl Acad Sci U S A. 2017; 114(19): 5029-34

PubMed Abstract | Publisher Full Text | Free Full Text

93. Tränkner D, Boulet A, Peden E, et al:: A Microglia Sublineage Protects from Sex-Linked Anxiety Symptoms and Obsessive Compulsion. Cell Rep. 2019; 29(4): 791-799.e3.

PubMed Abstract | Publisher Full Text | Free Full Text | Faculty Opinions Recommendation

94. Ullrich M, Weber M, Post AM, et al:: OCD-like behavior is caused by dysfunction of thalamo-amygdala circuits and upregulated TrkB/ERK-MAPK signaling as a result of SPRED2 deficiency. Mol Psychiatry. 2018; 23(2): 444-58. PubMed Abstract | Publisher Full Text | Free Full Text | Faculty Opinions Recommendation

95. Phoenix TN, Temple S: Spred1, a negative regulator of Ras-MAPK-ERK, is enriched in CNS germinal zones, dampens NSC proliferation, and maintains ventricular zone structure. Genes Dev. 2010; 24(4): 45-56. PubMed Abstract | Publisher Full Text | Free Full Text

96. van de Vondervoort I, Poelmans G, Aschrafi A, et al:: An integrated molecular landscape implicates the regulation of dendritic spine formation through insulin-related signalling in obsessive-compulsive disorder. $J$ Psychiatry Neurosci. 2016; 41(4): 280-5. PubMed Abstract | Publisher Full Text | Free Full Text

97. Bralten J, Widomska J, Witte WD, et al:: Shared genetic etiology between obsessive-compulsive disorder, obsessive-compulsive symptoms in the population, and insulin signaling. Transl Psychiatry. 2020; 10(1): 121. PubMed Abstract | Publisher Full Text | Free Full Text | Faculty Opinions Recommendation

98. van de Vondervoort IIGM, Amiri H, Bruchhage MMK, et al.: Converging evidence points towards a role of insulin signaling in regulating compulsive behavior. Transl Psychiatry. 2019; 9(1): 225.

PubMed Abstract | Publisher Full Text | Free Full Text | Faculty Opinions Recommendation

99. Casey BJ, Glatt CE, Lee FS: Treating the Developing versus Developed Brain Translating Preclinical Mouse and Human Studies. Neuron. 2015; 86(6): 1358-68.

PubMed Abstract | Publisher Full Text | Free Full Text

100. Noh HJ, Tang R, Flannick J, et al:: Integrating evolutionary and regulatory information with a multispecies approach implicates genes and pathways in obsessive-compulsive disorder. Nat Commun. 2017; 8(1): 774 PubMed Abstract | Publisher Full Text | Free Full Text

101. Viswanath B, Rao NP, Narayanaswamy JC, et al.: Discovery biology of neuropsychiatric syndromes (DBNS): A center for integrating clinical medicine and basic science. BMC Psychiatry. 2018; 18(1): 106. PubMed Abstract | Publisher Full Text | Free Full Text

102. Rodríguez N, Morer A, González-Navarro EA, et al:: Inflammatory dysregulation of monocytes in pediatric patients with obsessive-compulsive disorder. J Neuroinflammation. 2017; 14(1): 261. PubMed Abstract | Publisher Full Text | Free Full Text

103. Özyurt G, Binici NC: The neutrophil-lymphocyte ratio and plateletlymphocyte ratio in adolescent obsessive-compulsive disorder: Does comorbid anxiety disorder affect inflammatory response? Psychiatry Res. 2019; 272: 311-5. PubMed Abstract | Publisher Full Text | Faculty Opinions Recommendation

104. Bearden CE, Thompson PM: Emerging Global Initiatives in Neurogenetics: The Enhancing Neuroimaging Genetics through Meta-analysis (ENIGMA) Consortium. Neuron. 2017; 94(2): 232-6. PubMed Abstract | Publisher Full Text | Free Full Text

105. Hibar DP, Cheung JW, Medland SE, et al:: Significant concordance of genetic variation that increases both the risk for obsessive-compulsive disorder and the volumes of the nucleus accumbens and putamen. Br J Psychiatry. 2018; 213(1): 430-6. PubMed Abstract | Publisher Full Text | Free Full Text

106. Tang W, Zhu Q, Gong X, et al.: Cortico-striato-thalamo-cortical circuit abnormalities in obsessive-compulsive disorder: A voxel-based morphometric and fMRI study of the whole brain. Behav Brain Res. 2016; 313: 17-22. PubMed Abstract | Publisher Full Text

107. Denys D, Mantione M, Figee M, et al.: Deep brain stimulation of the nucleus accumbens for treatment-refractory obsessive-compulsive disorder. Arch Gen 
Faculty Opinions

Faculty Reviews 2020 9:(30)

Psychiatry. 2010; 67(10): 1061-8. PubMed Abstract | Publisher Full Text | Faculty Opinions Recommendation

108. Mulligan KA, Cheyette BNR: Neurodevelopmental Perspectives on Wit Signaling in Psychiatry. Mol Neuropsychiatry. 2017; 2(4): 219-46. PubMed Abstract | Publisher Full Text | Free Full Text

109. Chamberlain SR, Menzies L: Endophenotypes of obsessive-compulsive disorder: Rationale, evidence and future potential. Expert Rev Neurother. 2009; 9(8): 1133-46. PubMed Abstract | Publisher Full Text

110. Gottesman II, Gould TD: The endophenotype concept in psychiatry: Etymology and strategic intentions. Am J Psychiatry. 2003; 160(4): 636-45. PubMed Abstract | Publisher Full Text

111. lacono WG: Endophenotypes in psychiatric disease: Prospects and challenges. Genome Med. 2018; 10(1): 11.

PubMed Abstract | Publisher Full Text | Free Full Text

112. Zartaloudi E, Laws KR, Bramon E: Endophenotypes of executive functions in obsessive compulsive disorder? A meta-analysis in unaffected relatives. Psychiatr Genet. 2019; 29(6): 211-9.

PubMed Abstract | Publisher Full Text | Faculty Opinions Recommendation

113. Brown L, Fum S, Hag SB, et al.: Clinical Utilization of Pharmacogenetics in Psychiatry - Perspectives of Pharmacists, Genetic Counselors, Implementation Science, Clinicians, and Industry. Pharmacopsychiatry. 2020; 53(4): 162-73. PubMed Abstract | Publisher Full Text

114. Zai G, BrandI EJ, Müller DJ, et al:: Pharmacogenetics of antidepressant treatment in obsessive-compulsive disorder: An update and implications for clinicians. Pharmacogenomics. 2014; 15(8): 1147-57. PubMed Abstract | Publisher Full Text

115. Win H, Samuel JF, Wang $Y$, et al.: Whole-genome association analysis of treatment response in obsessive-compulsive disorder. Mol Psychiatry. 2016; 21(2): 270-6.

PubMed Abstract | Publisher Full Text | Free Full Text
116.

Lisoway AJ, Zai G, Tiwari AK, et al:: Pharmacogenetic evaluation of a DISP1 gene variant in antidepressant treatment of obsessive-compulsive disorder. Hum Psychopharmacol. 2018; 33(4): e2659.

PubMed Abstract | Publisher Full Text | Faculty Opinions Recommendation

117. Li T, Kim A, Rosenbluh J, et al:: GeNets: A unified web platform for network-based genomic analyses. Nat Methods. 2018; 15(7): 543-6. PubMed Abstract | Publisher Full Text | Free Full Text | Faculty Opinions Recommendation

118. Falcón-Moya R, Losada-Ruiz P, Rodríguez-Moreno A: Kainate Receptor-Mediated Depression of Glutamate Release Involves Protein Kinase A in the Cerebellum. Int J Mol Sci. 2019; 20(17): 4124.

PubMed Abstract | Publisher Full Text | Free Full Text

119. Missler M, Südhof TC, Biederer T: Synaptic cell adhesion. Cold Spring Herb Perspect Biol. 2012; 4(4): a005694. PubMed Abstract | Publisher Full Text | Free Full Text

120. Solecki DJ: Sticky situations: Recent advances in control of cell adhesion during neuronal migration. Gur Spin Neurobiol. 2012; 22(5): 791-8. PubMed Abstract | Publisher Full Text | Free Full Text

121. Cristino AS, Williams SM, Haw Z, et al.: Neurodevelopmental and neuropsychiatric disorders represent an interconnected molecular system. Mol Psychiatry. 2014; 19(3): 294-301. PubMed Abstract | Publisher Full Text

122. Oriss TB, Krishnamoorthy N, Ray $\mathrm{P}$, et al:: Dendritic cell c-kit signaling and adaptive immunity: Implications for the upper airways. Our Opin Allergy Chin Immunol. 2014; 14(1): 7-12.

PubMed Abstract | Publisher Full Text | Free Full Text

123. Kolata SM, Nakao K, Jeevakumar V, et al:: Neuropsychiatric Phenotypes Produced by GABA Reduction in Mouse Cortex and Hippocampus. Neuropsychopharmacology. 2018; 43(6): 1445-56.

PubMed Abstract | Publisher Full Text | Free Full Text | Faculty Opinions Recommendation 